\title{
Effect of Potassium Deficiency on the Reabsorption of Bicar- bonate in the Proximal Tubule of the Rat Kidney*
}

\author{
Floyd C. Rector, Jr., H. Allan Bloomer, † and Donald W. Seldin with the \\ TECHNiCAl assistance of MaRTha Huddleston \\ (From the Department of Internal Medicine, the University of Texas Southwestern Medical \\ School, Dallas, Texas)
}

Potassium deficiency accelerates the secretion of $\mathrm{H}^{+}$ions by the kidney; in consequence the net excretion of acid (ammonia and titratable acid-bicarbonate) into the urine and the capacity to reabsorb filtered $\mathrm{HCO}_{3}{ }^{-}$are increased (1-7). Although the precise mechanism involved has not been identified, Berliner, Kennedy, and Orloff (8), on the basis of the demonstrated reciprocal relationship between $\mathrm{H}^{+}$and $\mathrm{K}^{+}$secretion, proposed that these ions compete for a common secretory pathway in the distal nephron. Consequently, $\mathrm{K}^{+}$ depletion, by lowering the concentration of $\mathrm{K}^{+}$at the competitive secretory site, would facilitate $\mathrm{H}^{+}$ secretion and increase the capacity of the distal tubule to reabsorb $\mathrm{HCO}_{3}^{-}$(9).

Certain observations, however, are difficult to reconcile with the theory of competitive inhibition. Rector, Buttram, and Seldin (10) found that the inhibitory effects of $\mathrm{K}^{+}$administration on $\mathrm{HCO}_{3}{ }^{-}$ reabsorption could not be overcome by raising intracellular $\mathrm{H}^{+}$concentration by respiratory acidosis. This observation, which is not consistent with the theory of competitive inhibition between $\mathrm{H}^{+}$ and $\mathrm{K}^{+}$, suggests that $\mathrm{K}^{+}$might reduce $\mathrm{H}^{+}$secretion by either noncompetitive inhibition or by alkalinizing the renal tubular cells. If alterations of intracellular $\mathrm{K}^{+}$were capable of changing the $\mathrm{pH}$ of renal tubular cells, two consequences might follow : first, the inverse relationship between $\mathrm{H}^{+}$and

* Submitted for publication May 4, 1964 ; accepted June 24, 1964.

Supported in part by U. S. Public Health Service grants HTS-5469 and 2A-5028 and in part by an American Heart Association grant.

$\dagger$ Work done during the tenure of a fellowship of the U. S. Public Health Service, grants HTS-5469 and 2A-5028. Present address: Department of Internal Medicine, University of Utah College of Medicine, Salt Iake City, Utah.
$\mathrm{K}^{+}$secretion could be the result of reciprocal changes in the intracellular concentrations of these two ions in the distal nephron, rather than competition for a common secretory pathway; second, by altering the $\mathrm{pH}$ of proximal tubular cells, changes in intracellular $\mathrm{K}^{+}$might influence $\mathrm{H}^{+}$ secretion even though this area of the nephron is not a site of $\mathrm{K}^{+}$secretion.

The present experiments in rats were designed to investigate whether $\mathrm{K}^{+}$deficiency accelerates $\mathrm{H}^{+}$ secretion in the distal nephron only, where $\mathrm{K}^{+}$is known to be secreted (11), or also in the proximal tubule, where we $(12)$, as well as others $(11,13)$, have demonstrated that $\mathrm{K}^{+}$is reabsorbed but not secreted. If the $\mathrm{HCO}_{3}{ }^{-}$reabsorptive capacity of the distal, but not the proximal tubule, were increased, the concentration of $\mathrm{HCO}_{3}{ }^{-}$in plasma and in glomerular filtrate would be maintained at a concentration far above the proximal reabsorptive capacity. Consequently, as $\mathrm{NaCl}$ and $\mathrm{H}_{2} \mathrm{O}$ were reabsorbed in the proximal tubule, the concentration of the unreabsorbed bicarbonate would rise, and proximal tubular fluid would become more alkaline than blood. In contrast, if the $\mathrm{HCO}_{3}{ }^{-}$reabsorptive capacity of the proximal tubule were increased either alone or with a proportionate increase in distal reabsorptive capacity, the concentration of $\mathrm{HCO}_{3}{ }^{-}$in plasma and glomerular filtrate would be maintained at a level near, but not exceeding, the proximal reabsorptive capacity. Therefore, the relative rates of $\mathrm{NaHCO}_{3}, \mathrm{NaCl}$, and $\mathrm{H}_{2} \mathrm{O}$ reabsorption would be similar to those of normal rats, and the concentration of $\mathrm{HCO}_{3}{ }^{-}$ in proximal fluid should fall below that in plasma, as it does normally. These two possibilities were examined by comparing the concentration of $\mathrm{HCO}_{3}{ }^{-}$in proximal tubular fluid in $\mathrm{K}^{+}$-deficient, alkalotic rats with that in normal rats and in rats made acutely alkalotic by an infusion of $\mathrm{NaHCO}_{3}$. 
TABLE I

Treatment and plasma composition of the experimental groups

\begin{tabular}{|c|c|c|c|c|c|c|}
\hline \multirow[b]{2}{*}{ Groul } & \multirow[b]{2}{*}{$\begin{array}{l}\text { No. of } \\
\text { rats }\end{array}$} & \multirow[b]{2}{*}{ Treatment } & \multicolumn{4}{|c|}{ Plasma* } \\
\hline & & & {$[\mathrm{K}]$} & $\mathrm{pH}$ & $\begin{array}{c}\mathrm{CO}_{2} \\
\text { content }\end{array}$ & $\mathrm{PCO}_{2}$ \\
\hline & & & $m E q_{\prime}^{\prime} L$ & & $m E q_{q}^{\prime} L$ & $m m \mathrm{Hg}$ \\
\hline Normal & 10 & None & $\begin{array}{r}4.5 \\
\pm 0.2\end{array}$ & $\begin{array}{r}7.39 \\
\pm 0.04\end{array}$ & $\begin{array}{r}26.6 \\
\pm 2.5\end{array}$ & $\begin{array}{r}40 \\
\pm 2\end{array}$ \\
\hline$\underset{\mathrm{NaHCO}_{3}}{\mathrm{II}}$ & 11 & $\begin{array}{l}0.15 \mathrm{M} \mathrm{NaHCO} \text { infu- } \\
\text { sion for } 2 \text { hours }\end{array}$ & $\begin{array}{r}3.8 \\
\pm 0.2\end{array}$ & $\begin{array}{r}7.57 \\
\pm 0.05\end{array}$ & $\begin{array}{r}39.8 \\
\pm 3.5\end{array}$ & $\begin{array}{r}45 \\
\pm 3\end{array}$ \\
\hline $\begin{array}{c}\text { III } \\
\text { Potassium- } \\
\text { deficient }\end{array}$ & 17 & $\begin{array}{l}\mathrm{SEDD} \dagger+\mathrm{Na}_{2} \mathrm{SO}_{4} \\
\quad+\text { DOCA } f \text { for } 7 \text { days }\end{array}$ & $\begin{array}{r}1.7 \\
\pm 0.3\end{array}$ & $\begin{array}{r}7.55 \\
\pm 0.03\end{array}$ & $\begin{array}{r}38.3 \\
\pm 2.3\end{array}$ & $\begin{array}{r}44 \\
\pm 3\end{array}$ \\
\hline
\end{tabular}

* Mean values $\pm \mathrm{SD}$.

† Standard electrolyte-deficient diet.

$\ddagger$ Desoxycorticosterone acetate.

\section{Methods}

Micropuncture studies were performed on three groups of male Sprague-Dawley rats. Groups I and II were fed rat pellet diet and tap water. Group I received no further treatment. Group II rats were infused with $0.15 \mathrm{M}$ $\mathrm{NaHCO}_{3}$ at the rate of $0.1 \mathrm{ml}$ per minute for 2 hours before collecting any samples of tubular fluid; the infusion was continued during the collection periods. This 2-hour infusion period permitted the blood $\mathrm{pH}$ and plasma $\mathrm{HCO}_{3}{ }^{-}$concentrations to attain reasonably stable values. Group III rats were made $\mathrm{K}^{+}$deficient by feeding them a standard electrolyte-deficient diet containing $1 \mathrm{mM} \mathrm{Na} 2 \mathrm{SO}_{4}$ daily and injecting. $5 \mathrm{mg}$ desoxycorticosterone acetate (DOCA) in oil intramuscularly daily for 7 days. All animals were fasted for 18 hours before the experiment to permit complete excretion of the dietary $\mathrm{Na}_{2} \mathrm{SO}_{4}$; the last injection of DOCA was 24 hours before the micropuncture study.

The rats were anesthetized with sodium pentobarbital and prepared for micropuncture as previously described (12), except that the left kidney was exposed through a flank incision. Samples of tubular fluid were aspirated into quinhydrone microelectrodes for the measurement of $\mathrm{pH}$. The site of collection was determined by microdissection after injecting the tubule with latex. At the end of the experiment blood was collected from the abdominal aorta for measurement of $\mathrm{pH}, \mathrm{CO}_{2}$ content, and $\mathrm{K}^{+}$.

The concentration of $\mathrm{HCO}_{3}^{-}$in tubular fluid was estimated by the following technique. The $\mathrm{pH}$ of tubular fluid was measured with quinhydrone microelectrodes prepared as described by Pierce and Montgomery (14). Immediately before use the microelectrodes were filled with mineral oil that had been equilibrated with $5 \% \mathrm{CO}_{2}$. Samples aspirated into the tip of the pipette-electrode quickly equilibrated to the same $\mathrm{PCO}_{2}$ as the mineral oil. The electrode tips were sealed by dipping them into egg albumin. The voltage difference between the quinhy- drone electrode and a saturated $\mathrm{KCl}$-calomel reference electrode was measured at $37^{\circ} \mathrm{C}$, with a General-Radio electrometer. The $\mathrm{pH}$ was calculated from the formula given by Pierce and Montgomery (14). Since the $\mathrm{pH}$ of these samples was measured at a constant $\mathrm{PCO}_{2}$ of approximately $40 \mathrm{~mm} \mathrm{Hg}$ in the electrode rather than at the actual $\mathrm{PCO}_{2}$ of plasma, the measured value was not the true intratubular $\mathrm{pH}$, but represented instead a measure of the $\mathrm{HCO}_{3}^{-}$concentration in the tubular fluid (15). The concentration of $\mathrm{HCO}_{3}{ }^{-}$in tubular fluid was calculated from the quinhydrone $\mathrm{pH}$ and the known $\mathrm{PCO}_{2}$ of the mineral oil in the electrode by the HendersonHasselbalch equation.

In an additional series of experiments in four rats made alkalotic by $\mathrm{NaHCO}_{3}$ infusion, the effect of acute reductions in glomerular filtration rate (GFR) on proximal acidification was investigated. Proximal $\mathrm{HCO}_{3}^{-}$ concentration was measured in the same tubule before and after constricting the aorta above the renal arteries. A silk ligature was passed around the aorta and threaded through a small glass capillary tube; when the ligature protruding from the capillary was tied around a small glass rod and twisted, the aorta was gently pulled against

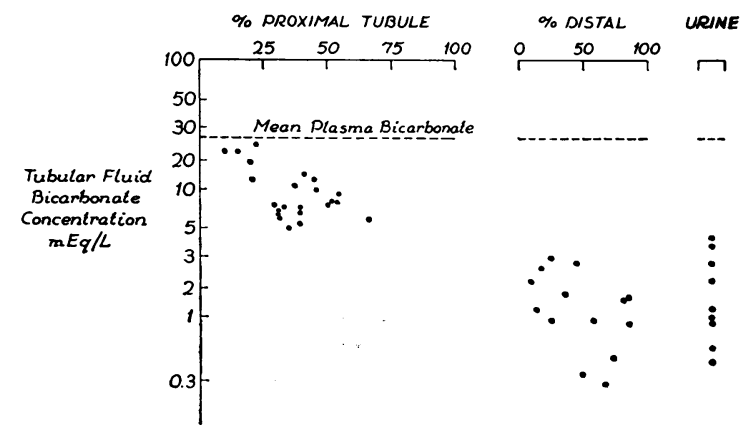

Fig. 1. Concentration of bicarbonate in tubulat FLUID AND URINE IN NORMAL RATS. 


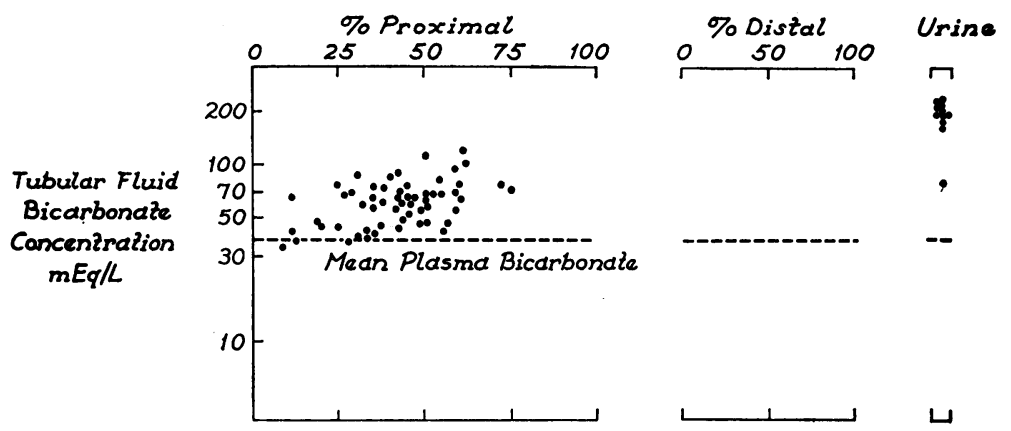

Fig. 2. Concentration of bicarbonate in tUbular fluid and URine in RATS INFUSED WITH $0.15 \mathrm{M} \mathrm{NAHCO}$ FOR 2 HOURS.

the glass tube. The degree of constriction was monitored by measuring the femoral blood pressure through a small polyethylene cannula with a Statham strain gauge and a Sanborn Twin-Viso recorder. Preliminary experiments established that reducing femoral blood pressure to approximately $60 \mathrm{~mm} \mathrm{Hg}$ lowered GFR by 50 to $65 \%$. During the control periods $0.15 \mathrm{M} \mathrm{NaHCO}_{3}$ was infused at a rate of $0.1 \mathrm{ml}$ per minute and inulin at a rate of $1 \mathrm{mg}$ per minute; after aortic constriction the infusion rates were reduced to $0.05 \mathrm{ml}$ per minute for $\mathrm{NaHCO}_{3}$ and $0.5 \mathrm{mg}$ per minute for inulin. Before and after aortic constriction blood was sampled from the jugular vein, and timed urine samples were collected from a bladder catheter for the measurement of inulin, $\mathrm{pH}$, and $\mathrm{CO}_{2}$ content.

Blood and urine $\mathrm{pH}$ were measured in a Beckman anaerobic glass electrode at $37^{\circ} \mathrm{C}$ with a Vibron $\mathrm{pH}$ meter. The $\mathrm{CO}_{2}$ contents were measured by the Natelson microgasometer. Serum $\mathrm{K}^{+}$was determined by an internal standard flame photometer. Inulin in blood and urine was measured by the method of Walser, Davidson, and Orloff (16).

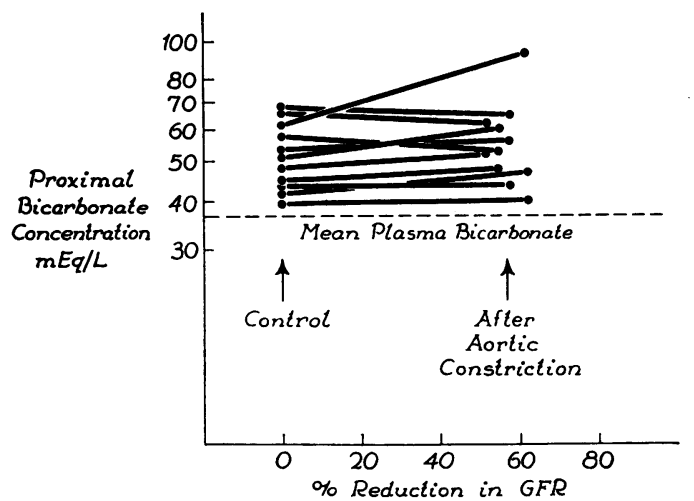

Fig. 3. EFFect of ACUTE REdUCtions in glomerular FILTRATION RATE (GFR) ON PROXIMAL BICARBONATE CONCENTRATION IN RATS INFUSED With $\mathrm{NaHCO}_{3}$. The bicarbonate concentrations from the same tubule before and after aortic constriction are connected by the solid lines. Only measurements from the middle third of the tubule are shown.

\section{Results}

The plasma composition of the three groups is shown in Table I. At the end of the micropuncture experiments the rats in group 1 had values for blood $\mathrm{pH}$, plasma $\mathrm{Pco}_{2}$ content, and $\mathrm{K}^{+}$concentration that were very similar to those obtained in rats in our laboratory not subjected to the micropuncture procedures. In group II the infusion of $0.15 \mathrm{M} \mathrm{NaHCO}_{3}$ for 2 hours before and during the experiment resulted in a severe metabolic alkalosis : blood $\mathrm{pH}$ of $7.57 \pm 0.05$ (SD), plasma $\mathrm{CO}_{2}$ content of $39.8 \pm 3.5$ mmoles per $\mathrm{L}$, and plasma $\mathrm{PCO}_{2}$ of $45 \pm 3 \mathrm{~mm} \mathrm{Hg}$. As expected, acute metabolic alkalosis caused a slight fall in the concentration of plasma $\mathrm{K}^{+}$to $3.8 \pm 0.2 \mathrm{mEq}$ per L. In group III the severe hypokalemia of $1.7 \pm 0.3 \mathrm{mEq}$ per $\mathrm{L}$ was associated with a marked metabolic alkalosis, with an acid-base composition almost identical to that in group II : blood $\mathrm{pH}$, $7.55 \pm 0.03$; plasma $\mathrm{CO}_{2}$ content, $38.3 \pm 2.3$ mmoles per L; and plasma $\mathrm{Pco}_{2}, 44 \pm 3 \mathrm{~mm} \mathrm{Hg}$.

The concentration of $\mathrm{HCO}_{3}{ }^{-}$in tubular fluid and

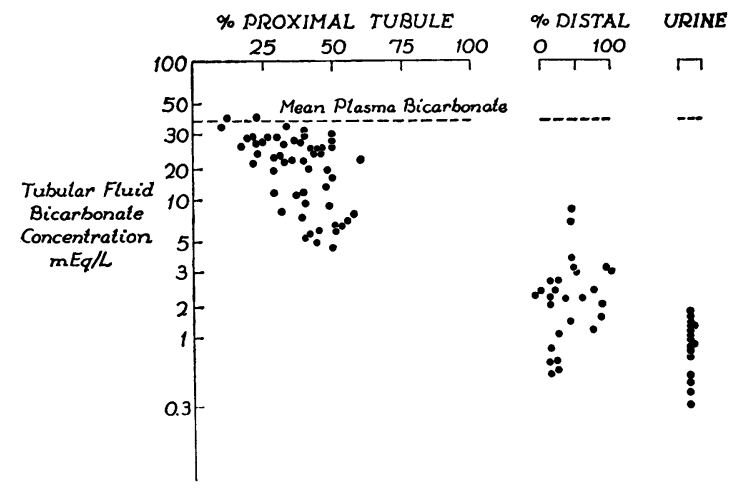

Fig. 4. Concentration of bicarbonate in tubular FLUID AND URINE IN POTASSIUM-DEFICIENT RATS. 
urine in the normal rats (group I) is shown in Figure 1. The concentration of $\mathrm{HCO}_{3}{ }^{-}$in proximal tubular fluid progressively fell, reaching values as low as $5 \mathrm{mEq}$ per $\mathrm{L}$. The average $\mathrm{HCO}_{3}^{-}$ concentration in the middle third of the proximal tubule was $7.5 \pm 2.2 \mathrm{mEq}$ per $\mathrm{L}$. These results are similar to those reported by Gottschalk, Lassiter, and Mylle (17).

In the rats made acutely alkalotic by the infusion of $\mathrm{NaHCO}_{3}$ (group II), the concentration of $\mathrm{HCO}_{3}{ }^{-}$in proximal tubular fluid rose to a level significantly higher than that in plasma (Figure 2 ). In the middle third of the proximal tubule the $\mathrm{HCO}_{3}{ }^{-}$concentration in every sample was higher than in plasma, averaging $57.8 \pm 13.5 \mathrm{mEq}$ per L.

Acutely lowering GFR had no effect on proximal bicarbonate concentration in the rats given $\mathrm{NaHCO}_{3}$ (Figure 3). Aortic constriction reduced the GFR by 50 to $60 \%$. Blood $\mathrm{pH}, \mathrm{CO}_{2}$ content, and $\mathrm{PCO}_{2}$ were the same before and after aortic constriction. Despite the marked reduction in GFR the concentration of $\mathrm{HCO}_{3}{ }^{-}$in individual proximal tubules was essentially the same after aortic constriction as before.

In contrast to results obtained in the acutely alkalotic rats, the concentration of $\mathrm{HCO}_{3}{ }^{-}$in proximal tubular fluid in the rats with hypokalemic alkalosis was lower than in plasma (Figure 4). In the middle third of the proximal tubule the $\mathrm{HCO}_{3}{ }^{-}$concentration of every sample was lower than that of plasma, falling from a mean concentration of $37.2 \pm 2.3 \mathrm{mEq}$ per $\mathrm{L}$ in plasma to a mean concentration of $17.8 \pm 7.5 \mathrm{mEq}$ per $\mathrm{L}$ in

TABLE II

Effect of potassium deficiency on acidification of proximal tubular fluid

\begin{tabular}{crrrrr}
\hline \hline & \multicolumn{2}{c}{ Plasma } & \multicolumn{2}{c}{ Proximal tubule* } \\
\cline { 3 - 5 } Groul & \multicolumn{1}{c}{$\mathrm{pH}$} & {$\left[\mathrm{HCO}_{3}-\right]$} & & $\mathrm{pH} \dagger$ & {$\left[\mathrm{HCO}_{3}^{-}\right]$} \\
\hline I & 7.39 & 25.4 & 6.88 & 7.5 \\
Normal & \pm 0.04 & \pm 2.5 & \pm 0.12 & \pm 2.2 \\
& & & & \\
II & 7.57 & 38.5 & 7.75 & 57.8 \\
$\mathrm{NaHCO}_{3}$ & \pm 0.05 & \pm 3.5 & \pm 0.15 & \pm 13.5 \\
III & 7.55 & 37.2 & 7.15 & 17.8 \\
Potassium- & \pm 0.03 & \pm 2.3 & \pm 0.27 & \pm 7.5 \\
deficient & & & & \\
\cline { 1 - 2 } & & & &
\end{tabular}

$*$ Mean $\pm \mathrm{SD}$ in middle third of proximal tubule.

t Quinhydrone $\mathrm{pH}$ of sample equilibrated with $5 \% \mathrm{CO}_{2}$. tubular fluid (Table II). The fluid entering the distal tubule contained almost no $\mathrm{HCO}_{3}{ }^{-}$, indicating that virtually all the filtered $\mathrm{HCO}_{3}{ }^{-}$had been reabsorbed in more proximal segments of the nephron.

\section{Discussion}

In the normal rat filtered $\mathrm{HCO}_{3}{ }^{-}$is reabsorbed in the proximal convoluted tubule at a rate relatively faster than the isosmotic reabsorption of water; consequently the concentration of $\mathrm{HCO}_{3}^{-}$ in the fluid issuing from the proximal tubule is less than that of plasma. In contrast, during acute alkalosis the concentration of $\mathrm{HCO}_{3}{ }^{-}$in plasma and glomerular filtrate exceeds the proximal reabsorptive capacity, so that as water is reabsorbed isosmotically (secondary to $\mathrm{NaCl}$ reabsorption), the unreabsorbed $\mathrm{HCO}_{3}^{-}$is concentrated to a level above that in plasma.

These results clearly indicate that the concentration of $\mathrm{HCO}_{3}{ }^{-}$in the fluid leaving the proximal tubule is determined not only by the rate of $\mathrm{HCO}_{3}{ }^{-}$ reabsorption $\left(\mathrm{R}_{\mathrm{NaHCO}_{3}}\right)$, but also by the rate of water reabsorption and the concentration of $\mathrm{HCO}_{3}{ }^{-}$in glomerular filtrate $\left(\left[\mathrm{HCO}_{3}^{-}\right]_{\mathrm{GF}}\right)$. Since $\mathrm{NaCl}$ and $\mathrm{NaHCO}_{3}$ are the principal osmotically active solutes whose removal promotes the isosmotic reabsorption of water, the directional changes in the $\mathrm{HCO}_{3}{ }^{-}$concentration in tubular fluid $\left(\left[\mathrm{HCO}_{3}^{-}\right]_{\mathrm{TF}}\right)$ can best be expressed in terms of the relative rates of $\mathrm{NaCl}$ and $\mathrm{NaHCO}_{3}$ reabsorption. For purposes of this discussion, the term relative rate is defined as the rate of reabsorption of a particular sodium salt divided by its concentration in glomerular filtrate. The relative rates for $\mathrm{NaCl}$ and $\mathrm{NaHCO}_{3}$ reabsorption are $\mathrm{R}_{\mathrm{NaCl}} /[\mathrm{NaCl}]_{\mathrm{GF}}$ and $\mathrm{R}_{\mathrm{NaHCO}_{3}} /\left[\mathrm{NaHCO}_{3}\right]_{\mathrm{GF}}$, respectively.

If the relative rates of $\mathrm{NaCl}$ and $\mathrm{NaHCO}_{3} \mathrm{re}^{-}$ absorption were equal, $\left[\mathrm{Cl}^{-}\right]_{\mathrm{TF}}$ and $\left[\mathrm{HCO}_{3}{ }^{-}\right]_{\mathrm{TF}}$ would not change, remaining equal to their concentrations in plasma and glomerular filtrate. If, on the other hand, the relative rate for $\mathrm{NaHCO}_{3}$ were greater than that for $\mathrm{NaCl},\left[\mathrm{HCO}_{3}{ }^{-}\right]_{\text {TF }}$ would fall below and $\left[\mathrm{Cl}^{-}\right]_{\mathrm{TF}}$ would rise above their respective concentrations in plasma, whereas if the relative rate for $\mathrm{NaHCO}_{3}$ were less than that for $\mathrm{NaCl}$, then $\left[\mathrm{HCO}_{3}^{-}\right]_{\mathbf{T F}}$ would rise and $\left[\mathrm{Cl}^{-}\right]_{\mathrm{TF}}$ would fall. 
Changes in $\left[\mathrm{NaHCO}_{3}\right]_{\mathrm{GF}}$ and $[\mathrm{NaCl}]_{\mathrm{GF}}$ would influence the directional change in $\left[\mathrm{HCO}_{3}{ }^{-}\right]_{\mathrm{TF}}$ only if $\mathrm{R}_{\mathrm{NaHCO}_{3}}$ and $\mathrm{R}_{\mathrm{NaCl}}$ were not linearly related to $\left[\mathrm{NaHCO}_{3}\right]_{\mathrm{GF}}$ and $[\mathrm{NaCl}]_{\mathrm{GF}}$. If $\mathrm{R}_{\mathrm{NaHCO}_{3}}$ and $\mathrm{R}_{\mathrm{NaCl}}$ were both linearly related to $\left[\mathrm{NaHCO}_{3}\right]_{\mathrm{GF}}$ and $[\mathrm{NaCl}]_{\mathrm{GF}}$, respectively, then the relationship between $\mathrm{R}_{\mathrm{NaHCO}_{3}} /\left[\mathrm{NaHCO}_{3}\right]_{\mathrm{GF}}$ and $\mathrm{R}_{\mathrm{NaCl}} /[\mathrm{NaCl}]_{\mathrm{GF}}$ obviously would not change as the composition of the glomerular filtrate was altered. From currently available micropuncture data $\mathrm{R}_{\mathrm{NaCl}}$ does in fact appear to be a linear function of $[\mathrm{NaCl}]_{\mathrm{GF}}$. Giebisch, Klose, and Windhager (18) and Lassiter, Gottschalk, and Mylle (19) found that raising $[\mathrm{NaCl}]_{\mathrm{GF}}$ by the infusion of $5 \%$ saline resulted in proportionate increases in $\mathrm{R}_{\mathrm{NaCl}}$. Clearance studies, however, clearly reveal that the over-all tubular reabsorption of $\mathrm{NaHCO}_{3}$ does not increase linearly as [Na$\left.\mathrm{HCO}_{3}\right]_{\mathrm{GF}}$ is elevated and, instead, exhibits a reabsorptive maximum (20). The present studies also indicate that proximal $\mathrm{R}_{\mathrm{NaHCO}_{3}}$ is a nonlinear function of $\left[\mathrm{NaHCO}_{3}\right]_{\mathrm{GF}}$; therefore, changes in $\left[\mathrm{NaHCO}_{3}\right]_{\mathrm{GF}}$ do alter the directional changes in proximal $\left[\mathrm{HCO}_{3}{ }^{-}\right]_{\mathrm{TF}}$.

In the normal rats $\left[\mathrm{HCO}_{3}^{-}\right]_{\mathrm{TF}}$ in proximal tubular fluid fell below that in plasma to a level of about $7.5 \mathrm{mEq}$ per L. Thus, in these normal rats, the relative rate of $\mathrm{NaHCO}_{3}$ reabsorption exceeded that for $\mathrm{NaCl}$. As $\left[\mathrm{NaHCO}_{3}\right]_{\mathrm{GF}}$ was acutely elevated by the infusion of $\mathrm{NaHCO}_{3}$, the directional change in $\left[\mathrm{HCO}_{3}^{-}\right]_{\mathrm{TF}}$ reversed, and $\left[\mathrm{HCO}_{3}{ }^{-}\right]_{\mathrm{TF}}$ rose to approximately $58 \mathrm{mEq}$ per $\mathrm{L}$ or roughly 1.5 times the concentration in plasma and glomerular filtrate. In the acutely alkalotic rats, therefore, the relative rate of $\mathrm{NaHCO}_{3}$ reabsorption was less than that for $\mathrm{NaCl}$. This clearly indicates that $\mathrm{R}_{\mathrm{NaHCO}_{3}}$ did not increase in linear fashion as $\left[\mathrm{NaHCO}_{3}\right]_{\mathrm{GF}}$ was raised, but instead exhibited saturation kinetics.

Potassium deficiency obviously altered the response of proximal $\mathrm{R}_{\mathrm{NaHCO}_{3}}$ to increased ( $\mathrm{Na}-$ $\left.\mathrm{HCO}_{3}\right]_{\mathrm{GF}}$. At the same high $\left[\mathrm{NaHCO}_{3}\right]_{\mathrm{GF}}$ as was present in the rats given $\mathrm{NaHCO}_{3}$ ( Table II), $\left[\mathrm{HCO}_{3}^{-}\right]_{\mathrm{TF}}$ fell below that in plasma and glomerular filtrate. The relative rate of $\mathrm{NaHCO}_{3}$ reabsorption, therefore, exceeded that for $\mathrm{NaCl}$ despite the high $\left[\mathrm{NaHCO}_{3}\right]_{\mathrm{GF}}$. Since the $[\mathrm{Na}-$ $\left.\mathrm{HCO}_{3}\right]_{\mathrm{GF}}$ and $[\mathrm{NaCl}]_{\mathrm{GF}}$ were approximately the same in the $\mathrm{K}^{+}$-deficient rats and the rats infused with $\mathrm{NaHCO}_{3}$, the reabsorptive ratio $\mathrm{R}_{\mathrm{NaHCO}_{3}}$ /
$\mathrm{R}_{\mathrm{NaCl}}$ must have been greater in the $\mathrm{K}^{+}$-deficient than in the acutely alkalotic rats.

Several factors might have been responsible for the relative increase in proximal $\mathrm{NaHCO}_{3}$ reabsorption in the $\mathrm{K}^{+}$-deficient rats. Holliday, Eagan, and Wirth (21) have reported that $\mathrm{K}^{+}$deficiency depresses the GFR in rats. It is conceivable, therefore, that the increased proximal acidification in the $\mathrm{K}^{+}$-deficient rats might have been the consequence of a fall in GFR. On an a priori basis, however, it is difficult to predict the effect of reduced GFR on proximal acidification, since clearance studies on intact animals have demonstrated that the reabsorption of both $\mathrm{NaCl}$ (22) and $\mathrm{NaHCO}_{3}$ (20) tend to decrease as GFR falls. Such studies, however, do not indicate the relative contributions of the proximal and distal nephron, nor do they establish the relative magnitudes in the reduction in $\mathrm{NaCl}$ and $\mathrm{NaHCO}_{3}$ reabsorption as GFR is decreased. For a reduction in GFR to account for the proximal acidification in the $\mathrm{K}^{+}$deficient rats, it would be necessary that $\mathrm{R}_{\mathrm{NaCl}}$ be depressed to a greater extent than $\mathrm{R}_{\mathrm{NaHCO}_{3}}$, so that the reabsorptive ratio $\mathrm{R}_{\mathrm{NaHCO}_{3}} / \mathrm{R}_{\mathrm{NaCl}}$ is increased. Therefore, to elucidate the role of GFR, if any, in proximal acidification, GFR was reduced 50 to $60 \%$ by constricting the aorta in rats made acutely alkalotic by an infusion of $\mathrm{NaHCO}_{3}$ (Figure 3 ). Despite these marked reductions in GFR the tubular fluid remained alkaline. This must mean that a reduction in GFR depresses $R_{\mathrm{NaCl}}$ and $\mathrm{R}_{\mathrm{NaHCO}_{3}}$ to the same extent and therefore cannot lower the concentration of $\mathrm{HCO}_{3}{ }^{-}$in proximal tubular fluid. It is concluded that acidification of proximal tubular fluid in $\mathrm{K}^{+}$deficiency cannot be due to a fall in GFR.

Since variations in plasma $\mathrm{CO}_{2}$ tension are known to influence the capacity to reabsorb filtered $\mathrm{HCO}_{3}^{-}$, the mild hypercapnia (Table I) observed in the hypokalemic rats might account in part for the relative increase in $\mathrm{R}_{\mathrm{NaHCO}_{3}}$. However, this cannot account for the relatively greater $\mathrm{R}_{\mathrm{NaHCO}}$ in the hypokalemic rats, since the plasma $\mathrm{CO}_{2}$ tensions were identical in the rats made alkalotic with $\mathrm{NaHCO}_{3}$ and the rats with hypokalemic alkalosis (Table I). These experiments indicate, therefore, that $\mathrm{K}^{+}$deficiency per se is in some way responsible for the increased $\mathrm{R}_{\mathrm{NaHCO}_{3}}$ relative to $\mathrm{R}_{\mathrm{NaCl}}$ in the proximal convoluted tubule.

Potassium deficiency might augment the rate 
of $\mathrm{NaHCO}_{3}$ relative to $\mathrm{NaCl}$ reabsorption in one of several ways. One possibility is that, rather than a primary increase in the rate of $\mathrm{NaHCO}_{3}$ reabsorption, the rate of $\mathrm{NaCl}$ reabsorption is decreased. The reabsorption of $\mathrm{NaCl}$ is thought to be mediated by an ion exchange pump at the peritubular surface of the cell that pumps $\mathrm{Na}^{+}$out of $\mathrm{K}^{+}$into the cell, with $\mathrm{Cl}^{-}$ moving passively from lumen to blood (23). It is conceivable, therefore, that a decreased concentration of $\mathrm{K}^{+}$in blood would decrease the rate of $\mathrm{Na}^{+}$transport out of the cell and consequently decrease $\mathrm{NaCl}$ reabsorption. Giebisch and Windhager (24) have reported that lowering the concentration of $\mathrm{K}^{+}$in peritubular fluid decreased the rate of proximal $\mathrm{Na}^{+}$reabsorption in Necturus. Bank and Aynedjian (25), however, have recently found that the percentage of glomerular filtrate reabsorbed in the proximal tubules of $\mathrm{K}^{+}$-deficient rats is increased. Unfortunately, this study, while suggestive, is not conclusive; the GFR was reduced in the animals studied by Bank and Aynedjian, so that their results do not necessarily exclude a decrease in the rate of $\mathrm{NaCl}$ reabsorption. More important, however, is the fact that $\mathrm{K}^{+}$deficiency not only augments proximal acidification but also increases the absolute rate of $\mathrm{NaHCO}_{3}$ reabsorption $(3,7)$. Therefore, while a primary decrease in $\mathrm{R}_{\mathrm{NaCl}}$ could account for the fall in proximal $\left[\mathrm{HCO}_{3}^{-}\right]_{\mathrm{TF}}$, it could not account for the greatly augmented $\mathrm{HCO}_{3}$ - reabsorptive capacity associated with $\mathrm{K}^{+}$depletion.

It is much more probable, therefore, that the effects of $\mathrm{K}^{+}$deficiency on proximal acidification are a reflection of an increase in the rate of $\mathrm{H}^{+}$ secretion. Since it has previously been shown that $\mathrm{K}^{+}$is reabsorbed (11-13), but not secreted in the proximal tubule, this effect cannot be due to competition between $\mathrm{H}^{+}$and $\mathrm{K}^{+}$at a common secretory site on the luminal surface of the cell. Although it is possible that $\mathrm{K}^{+}$inhibits $\mathrm{H}^{+}$secretion by some noncompetitive process, it is more likely that $\mathrm{K}^{+}$influences $\mathrm{H}^{+}$secretion by changing the $\mathrm{pH}$ of renal tubular cells. Anderson and Mudge (26) demonstrated that in kidney slices $\mathrm{HCO}_{3}^{-}$moves into or out of the cells together with $\mathrm{K}^{+}$. Thus, $\mathrm{K}^{+}$deficiency might decrease the steady-state concentration of $\mathrm{HCO}_{3}{ }^{-}$in the tubular cells so that at any given $\mathrm{PCO}_{2}$ there would be a lower intracellular $\mathrm{pH}$. As a result of this in- crease in intracellular $\mathrm{H}^{+}$concentration, the secretion of $\mathrm{H}^{+}$would be stimulated, thereby augmenting the rate of $\mathrm{NaHCO}_{3}$ reabsorption.

Potassium deficiency might lower the steadystate concentration of $\mathrm{HCO}_{3}{ }^{-}$in the tubular cells by accelerating the rate of removal of $\mathrm{HCO}_{3}{ }^{-}$ions. According to current concepts, the $\mathrm{HCO}_{3}{ }^{-}$generated in the cell by the combination of $\mathrm{H}_{2} \mathrm{CO}_{3}$ formation and $\mathrm{H}^{+}$secretion moves out of the cell along electrochemical gradients. An important factor in $\mathrm{HCO}_{3}{ }^{-}$removal, therefore, would be the potential difference across the peritubular membrane. We have found that the resting membrane potential of skeletal muscle increases from a mean value of $89 \pm 1$. (SD) $\mathrm{mv}$ in normal rats to $97 \pm 3 \mathrm{mv}$ in $\mathrm{K}^{+}$-deficient rats (27). If similar changes in potential difference occurred across the peritubular surface of the renal epithelial cells, the electrical force driving $\mathrm{HCO}_{3}{ }^{-}$out of the cell would be commensurately increased and could therefore result in a decreased steady-state intracellular concentration of $\mathrm{HCO}_{3}^{-}$.

Although it is tempting to speculate that $\mathrm{K}^{+}$deficiency affects the proximal and distal tubules in a similar fashion, these experiments cast no light on the relation between $\mathrm{K}^{+}$and $\mathrm{H}^{+}$secretion in the distal nephron. The conclusion that $\mathrm{K}^{+}$deficiency augments $\mathrm{H}^{+}$secretion in the proximal tubule by lowering intracellular $\mathrm{pH}$ cannot be extrapolated to the distal nephron where competition between $\mathrm{K}^{+}$and $\mathrm{H}^{+}$for a common secretory pathway may well be operative.

\section{Summary}

Proximal acidification was investigated by measuring $\mathrm{HCO}_{3}^{-}$concentration in tubular fluid in normal rats, rats made acutely alkalotic by an infusion of $\mathrm{NaHCO}_{3}$, and rats with hypokalemic alkalosis. The concentration of $\mathrm{HCO}_{3}^{-}$in the proximal tubule of normal rats fell to an average value of $7.5 \mathrm{mEq}$ per $\mathrm{L}$, a value significantly lower than that of plasma. Despite a comparable degree of metabolic alkalosis in the rats given $\mathrm{Na}$ $\mathrm{HCO}_{3}$ and the hypokalemic rats, every sample of proximal fluid in the rats given $\mathrm{NaHCO}_{3}$ had a higher $\mathrm{HCO}_{3}{ }^{-}$concentration than plasma, whereas every proximal sample in the hypokalemic rats had a lower $\mathrm{HCO}_{3}^{-}$concentration than plasma. This clearly indicates that $\mathrm{K}^{+}$deficiency increases 
the capacity of the proximal convoluted tubule to reabsorb filtered $\mathrm{HCO}_{3}^{-}$. Since $\mathrm{K}^{+}$is not secreted in the proximal tubule, the effect of $\mathrm{K}^{+}$deficiency cannot be due to decreased competitive inhibition at a common $\mathrm{H}^{+}-\mathrm{K}^{+}$secretory pathway. It is postulated that $\mathrm{K}^{+}$depletion stimulates proximal $\mathrm{H}^{+}$secretion by producing an intracellular acidosis.

\section{References}

1. Kennedy, T. J., Jr., J. H. Winkley, and M. F. Dunning. Gastric alkalosis with hypokalemia. Amer. J. Med. 1949, 6, 790.

2. Broch, O. J. Low potassium alkalosis with acid urine in ulcerative colitis. Scand. J. clin. Lab. Invest. 1950, 2, 113.

3. Roberts, K. E., H. T. Randall, H. L. Sanders, and M. Hood. Effects of potassium on renal tubular reabsorption of bicarbonate. J. clin. Invest. 1955, 34, 666.

4. Seldin, D. W., F. C. Rector, Jr., N. Carter, and J. Copenhaver. The relation of hypokalemic alkalosis induced by adrenal steroids to renal acid secretion (abstract). J. clin. Invest. 1954, 33, 965.

5. Iacobellis, M., E. Muntwyler, and G. E. Griffen. Enzyme concentration changes in the kidneys of protein- and/or potassium-deficient rats. Amer. J. Physiol. 1954, 178, 477.

6. Iacobellis, M., E. Muntwyler, and G. E. Griffen. Kidney glutaminase and carbonic anhydrase activity and tissue electrolyte composition in potassium deficient dogs. Amer. J. Physiol. 1955, 183, 395.

7. Giebisch, G., M. B. Macleod, and R. F. Pitts. Effect of adrenal steroids on renal tubular reabsorption of bicarbonate. Amer. J. Physiol. 1955, 183, 377.

8. Berliner, R. W., T. J. Kennedy, Jr., and J. Orloff. Relationship between acidification of the urine and potassium metabolism. Amer. J. Med. 1951, 11, 274.

9. Berliner, R. W., T. J. Kennedy, Jr., and J. Orloff. Factors affecting the transport of potassium and hydrogen ions by the renal tubules. Arch. int. Pharmacodyn. 1954, 97, 299.

10. Rector, F. C., Jr., H. Buttram, and D. W. Seldin. An analysis of the mechanism of the inhibitory influence of $\mathrm{K}^{+}$on renal $\mathrm{H}^{+}$secretion. J. clin. Invest. 1962, 41, 611.

11. Malnic, G., R. M. Klose, and G. Giebisch. Micropuncture study of renal potassium excretion in the rat. Amer. J. Physiol. 1964, 206, 674.
12. Bloomer, H. A., F. C. Rector, Jr., and D. W. Seldin. The mechanism of potassium reabsorption in the proximal tubule of the rat. J. clin. Invest. 1963, 42, 277.

13. Marsh, D. J., K. J. Ullich, and G. Rumrich. Micropuncture analysis of the behavior of potassium ions in rat renal cortical tubules. Pflügers Arch. ges. Physiol. 1963, 277, 107.

14. Pierce, J. A., and H. Montgomery. A microquinhydrone electrode: its application to the determination of the $\mathrm{pH}$ of glomerular urine of Necturus. J. biol. Chem. 1935, 110, 763.

15. Clapp, J. R., J. F. Watson, and R. W. Berliner. Osmolality, bicarbonate concentration, and water reabsorption in the proximal tubule of the dog nephron. Amer. J. Physiol. 1963, 205, 273.

16. Walser, M., D. G. Davidson, and J. Orloff. The renal clearance of alkali-stable inulin. J. clin. Invest. $1955,34,1520$.

17. Gottschalk, C. W., W. E. Lassiter, and M. Mylle. Localization of urine acidification in the mammalian kidney. Amer. J. Physiol. 1960, 198, 581.

18. Giebisch, G., R. M. Klose, and E. E. Windhager. Micropuncture study of hypertonic sodium loading in the rat. Amer. J. Physiol. 1964, 206, 687.

19. Lassiter, W. E., M. Mylle, and C. W. Gottschalk Net transtubular movement of water and urea in saline diuresis. Amer. J. Physiol. 1964, 206, 669.

20. Pitts, R. F., and W. D. Lotspeich. Bicarbonate and the renal regulation of acid base balance. Amer. J. Physiol. 1946, 147, 138.

21. Holliday, M. A., T. Eagan, and P. Wirth. Inulin and free water clearance studies in potassiumdeficient rats (abstract). J. Dis. Child. 1958, 96, 524.

22. Wesson, L. G., Jr. Glomerular and tubular factors in the renal excretion of sodium chloride. Medicine (Baltimore) 1957, 36, 281.

23. Giebisch, G. Measurements of electrical potential differences on single nephrons of the perfused $\mathrm{Nec}$ turus kidney. J. gen. Physiol. 1961, 44, 659.

24. Giebisch, G., and E. E. Windhager. Characterization of renal tubular transport of sodium chloride and water as studied in single nephrons. Amer. J. Med. 1963, 34, 1.

25. Bank, N., and H. S. Aynedjian. A micropuncture study of the renal concentrating defect of potassium depletion (abstract). Bull. N. Y. Acad. Med. 1964, 40, 65.

26. Anderson, H. M., and G. H. Mudge. The effect of potassium on intracellular bicarbonate in slices of kidney cortex. J. clin. Invest. 1955, 34, 1691.

27. Herbin, F., F. C. Rector, Jr., and D. W. Seldin. Unpublished observations. 